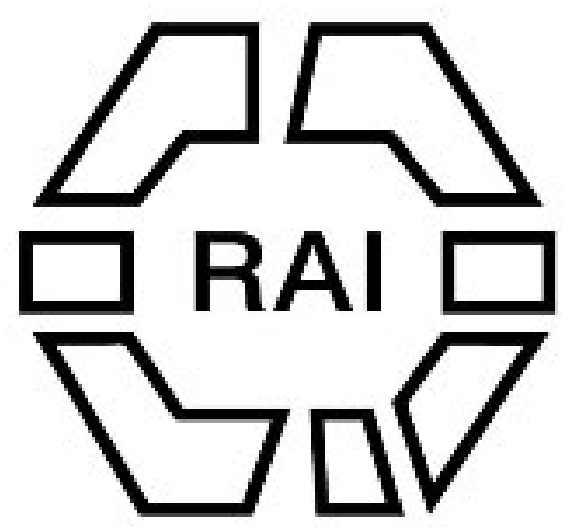

Songs and Specimens of the Language of New Georgia, Solomon Islands Author(s): B. T. Somerville and Sidney H. Ray

Source: The Tournal of the Anthropological Institute of Great Britain and Ireland, Vol. 26 (1897), pp. 436-453

Published by: Royal Anthropological Institute of Great Britain and Ireland

Stable URL: http://www.jstor.org/stable/2842015

Accessed: 10/06/2014 03:21

Your use of the JSTOR archive indicates your acceptance of the Terms \& Conditions of Use, available at http://www.jstor.org/page/info/about/policies/terms.jsp

JSTOR is a not-for-profit service that helps scholars, researchers, and students discover, use, and build upon a wide range of content in a trusted digital archive. We use information technology and tools to increase productivity and facilitate new forms of scholarship. For more information about JSTOR, please contact support@jstor.org. 
Mr. James Edge-Partington sends the following corroboree music from the Burnett River, Queensland, forwarded to him by Mr. Charles Handley :-

CALL.

\section{Burnett River Corroboree.}
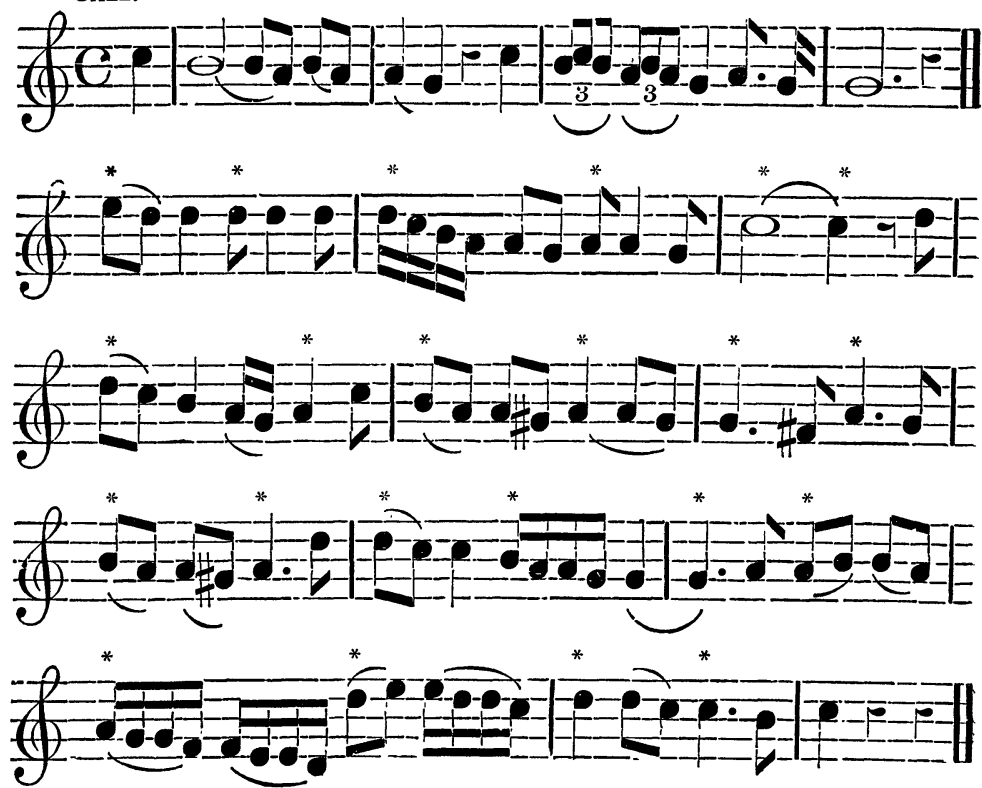

* Signifies the beat of boomerangs, nullah nullahs, etc., while the gins pad the opossum skins.

\section{Songs and Specimens of the Language of New Georgia,}

Solomon Islands. Collected by Lieatenant B. T. SomerVILLE, R.N.; with an Introductory Notice of Melanesian and New Guinea Songs, by SidNeY H. RAY.

\section{PART I. Introductory, bT Sidney H. RaY.}

It is a remarkable characteristic of the Song-Literature of Melanesia and New Guinea, that only in a very few examples has it been possible to give a translation of the words used, which will convey sense. Wherever songs have been collected, whether in F'iji, in Banks' Islands, New Hebrides, Solomon Islands or New Guinea, they are only partially intelligible. They are so, even to the natives themselves who sing them, and all the efforts of missionaries and others acquainted with the languages often fail to remove the obscurity. When, however, the songs are of some length and become narrative or historical poems they are much more intelligible, although containing still many obscure passages. Lieutenant Somerville, during his recent ethnological inquiries in 
New Georgia,' collected and sent to me several specimens of native songs, and these have suggested the collection and illustration of specimens from other parts of Melanesia and New Guinea, with references to the published literature on the subject.

\section{Fiji Songs.}

An account of Fijian versification with specimens was given by Hale in the Philology of United States Exploring Expedition,: and some further specimens have been given by Waterhouse in "The King and People of Fiji,"3 and by A. S. Gatschet." The latter are mostly derived from the collection of Rev. Lorimer Fison. But by far the most important notice of Fijian literature of this kind is a paper read at the Ninth Congress of Orientalists by Sir Arthur Gordon (now Lord Stanmore), on Fijian Poetry, ${ }^{5}$ in which is given various translated portions of songs.

In Fiji songs are of two kinds. The sere, sung or chanted sitting, and the meke, sung to accompany dances, or during the preparation of kava (yagona). It is noted that the latter especially are "very ancient and very unintelligible," that the songs are still an essential part of the lives of the people and are composed as occasion offers. Concerning sacred songs, Sir Arthur Gordon remarks as follows: "The sacred songs are exceedingly difficult to translate. This difficulty is due to several causes. One is that the language in which they are written differs from that in everyday use, whether only in being older, or as being purposely couched in different terms, I do not venture to pronounce positively, though my opinion inclines strongly in the latter direction. Another is to be found in the extremely elliptical and allusive nature of the phrases used, A third and one often not sufficiently thought of, is that most of them were intended to be acted, each singer or band of singers having a distinctly assigned part. To read one of them straight through is like reading a scene in a play in which there is a good deal of animated conversation and action, as if it were printed without any punctuation, without any hint that there is more than one speaker and without stage directions or changes of scene."

As specimens of Fijian songs in the native language I extract the following from Waterhouse. ${ }^{6}$ No translation was given by the collector.

1 See page 357.

2 United States Exploring Expedition, commanded by Charles Wilkes, U.S.N., during 1838-42, vol. vi, "Lthnography and Philology," by Horatio Hale. Philadelphia, 1846. 4to.

3 "The King and People of Fiji," by Joseph Waterhouse. London, 1866. 8vo.

4 "Specimens of Fiji Dialects," edited from manuscripts of Rev. Lorimer Fison, by A. S. Gatschet, in "Internat. Zeitschrift für Allgemeine Sprachwissenschaft," II Band. Leipzig, 1885, pp. 193-208.

3 "On Fijian Poetry," by Sir Arthur Gordon, in "Transactions of the Ninth Internat. Congress of Orientalists," vol. ii. London, 1893, pp. 731-753.

6 "King and People of Fiji," p. 425.

VOL. XXVI. 
Song of the Tobacco. (Vanua Lava.) It may be provincialised.

Dru taki waitui, dru tale;

Cici muri ko Lewatagane;

Sa maqa na tavoko e na masi ?

A tavako li ka koto mai vale,

Qai la'ki soli kei na yakavi.

Solia vakacara caviraki ?

Qisomakina ki na tulu ni vale.

Ualili mai e dua na tobe,

Ualili mai yasa mai cake,

Au cata na vakawati ni qase,

E dua vei au na gone

Mei vivivi ni tavakoe.

War Song. (Mbau). ${ }^{1}$

Ai tei vovo, tei vovo,

E ya, e ya, e ya, e ya;

Tei vovo, tei vovo

$\mathrm{E}$ ya, e ya, e ya, e ya.

Rai tu mai ; rai tu mai;

Oi au a viriviri kemu bai.

Rai tu mai; rai tu mai;

Oi au a viriviri kemu bai.

Toa alewa tagane

Veico, veico, veico.

Au tabu moce koi au

Au moce ga ki domo ni biau.

E luvu koto ki ra nomu waga,

E kaya beka au sa luva sara.

Nomu bai e wawa more

Au a tokia ka tasere.

\section{Banks' 1slands Songs.}

An account of the song dialects of the Banks' Islands is given by Rev. Dr. Codrington in his work on the Melanesian Languages. Speaking of the Songs of Mota he points out :

1. That the songs are never made in the common language, nor is their language that of any neighbouring place.

2. Each island has its own song dialect.

3. There is nothing to prove that the song dialect is an archaic form of the common language.

It is also shown that the differences from the common language " consist ( 1 ) in the casting out of vowels and consequent contraction

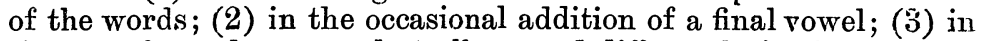
the use of words not used at all or used differently in the coinmon language; (4) in the imitation of foreign forms.

In Mota the person composing a song is called a towtowoas, one who measures, towo, a song as. The song is called after the person

1 "King and People of Fiji," p. 320. 
who is the subject of it, and is na asina, his song, it is na towona, his measure, of the poet, who is said to tara the subject of the song. To chant the song is we sur o as, to draw out the song.

I quote from. Dr. Codrington ${ }^{1}$ a part of a song about Bishop Selwyn, in the song dialect of Mota, Sugarloaf Island, and also a part of the same song in the Motlav, Saddle Island Dialect.

\section{Mota.}

Oeoewa wu roro sa? naroron i Besope ni gam tal na Vano lave; nalnik na lan lave, nasrik na ar Merlav, ni se turtur ale lame; gis nok melov ok; melov rer me rere levran Rohenqon, nam loslos wore sur na te mul Ulsilane, ro Tingormew se tur gor norue.

\section{Motlav.}

Aeoewae! wo reronse? wo reron e Besove ni gamtel weveno mee, nalni nelenlav, e nasri neer Merlav ni se turture le lame; gis wo melovok; melovrer enrer levrane Rehirqon, nam loslos wor enaen te mul Olsilade, Retingormew se tur gor doro.

\section{Mota Prose Version.}

Oeoewa! o roro sa? na roron Bishop, we gamo tale o Vanua Lava; nalanik o lan lava, nasuruk o aru ta Meralava, ni we turtur alo lama; gis! nok molov aka, o molov rere me rere lo varan Rohengon, na me loslos wora, ape na te mule Ulsilane, ro Tingormew we tur goro narua.

\section{English.}

Oeoewa! News of what? News of the Bishop, he sails round Vanua Lava. My wind is a great wind, my bones are the Casuarina tree of Merlav; he stands in the sea. Oh! my sailing of the ship; the sailing on the flow of the sea has flowed into the bosom of Rohenqon; I am nothing but rejoiced because I shall go to New Zealand; Ro Tingormew withstands us two.

\section{Tanna Song, New Hebrides.}

The only specimen of Song literature which I have from Southern Melanesia is the following from the island of Tanna. It presents many of the features of the Fiji and Banks' Island songs, and though mainly in the Kwamera dialect, contains several Weasisi words, obscure phrases, and even borrowed and modified English words. The subject is the shooting of a Weasisi man named Yehlu (called Yeru in the song) by Pûsî. The Rev. W. Gray gives the song and notes as follows:-

Ua rên rên raô

Ua rên rên raô

Ua rên rên raô

Ua rên raô

These words have no meaning

Rên rên rĭnraô. so far as we know.

1 Codrington, Rev. R. H., "The Melanesian Langnages," Oxford, 1885, pp. 309 and 321 . 
2.

Awê ! Nîŭt keikei !

Awe! Nîŭt keikei !

Awe! Nîut keikei!

Irîpen îau

Yakatĕrĕng paison. ${ }^{2}$

3.

In kŭrî rĭneivî

In kŭrî rĭneivî

In kŭrî rĭneivî

Ravahî meven

Rŭmaha ravahêraka.

4.

Pŭpŭm tĭ-ratînta

Pŭpŭm tǐ-ratînuta

Pŭpŭm tĭ-ratîûta

Rĭnahtî $\hat{i}^{3}$ Yĕrŭ

Mahtî nûprei nirŭs.

5.

Awe! kaha Pûsî-(3 times.)

Rĭnarukî Yĕrû,

Mûranî neirŭs. ${ }^{6}$

6.

A wê nŭma îmak ! (3 times.)

Y̌ma afwê Pûsî

Rarûkî îan.

7.

Yĕrû ramasŭk-(3 times.)

Makwein abŏmŏs.

Awê, nŭrŭk Nŭpau.

8.

Awê, nŭrŭk Nŭpau! (3 times.)

Nŭrŭk Nŭpau!

Awê, Tata Yeru!

9.

Kahû ramasŭk. (3 times.)

Makwein abŏmŏs :-

Awê mŭrâk Yeru !

10.

Awê, nı̆ma îmak

Ti-arîêr

Mata nokweikwei.
2.

O beloved Niut. ${ }^{1}$

Lead me there.

That I may feel the poison.

3.

The evil spirit prompted.

He takes (it) and goes.

Rumaha takes (it) away.

4.

By and by he will ascend. ${ }^{4}$

He has shot at Yeru.

And shot the trunk of a nirus. ${ }^{5}$

5.

Aha! my grandfather Pusi;

He has shot Yeru,

And shoulders his snider.

6.

Oh, my kindred !

That fellow Pusi

Has shot me.

7.

Yeru keeps crying :-

And calls long :-

Oh, my child Nupau.

8.

Oh, my child Nupau $!^{8}$

My child Nupau!

Oh, my father Yeru.

9.

Kahu keeps crying, And calls long.

Oh, my father-in-law Yeru !

10.

Ob, my kindred

Stand you three there.

And look at the raw flesh of the wound). 
11.

Awê, yakinamapau!

Nĭma îmak tî-o

Mŭvihî îau.
11.

Alas! I have become weak. My kindred do ye (something), And take me.

Notes.- ${ }^{1}$ Niut is probably the spirit of a dead person who is supposed to gire help to his descendants when they set out a bowl of kava for him to drink. 2 Paison is the English word poison. 3 Rinahti is partly Weasisi and partly Kwamera dialect. ${ }^{4}$ Yeru was shot on rising ground. ${ }^{5}$ Nirus is a tree with poisonous bark. ${ }^{6}$ A corruption of the English word snider. ${ }^{8}$ Yeru's son with his wife Kahu arrive.

\section{New Guinea Songs.}

The few specimens of New Guinea songs known differ very little in general character from those of other parts. Macgillivray so long ago as $1852^{1}$ gave an untranslated song in the Tassai (Brumer Island dialect). The following are given by the Rev. James Chalmers. ${ }^{2}$

1. A Motu song sung on lakatoi, taught to Edae by the Spirit.

Bokibada oviria nanai, Ario viriu na bo veriauko ; Bokibada eraroi nanai, Irope umanai ela Dauko.
Ela lao nauaore diaia;

Pinuopa diaia uruero nairuovo, Ela lao melarava memeru.

2. Another of the same character.

Edae Siabo hidia daqai

Ba negea dobi,

Edae Siabo, Edae a Siabo, Edae tu mai.
Bava hadaqai balaru dobi, Edae Siabo, Edae a Siabo, Edae a Siabo, Edae Siabo Hidia hadaqai.

3. Kabadi songs used when gardening.

"All the young bananas are placed round the plantation ready for planting, the planter takes one of the best, stands in the centre and looks inland; holding in his hand the banana, he says :-

$$
\begin{aligned}
& \text { Lariba dubaduba o. } \\
& \text { Jaribari dubaduba o. } \\
& \text { Jaribakeri dubaduba o. } \\
& \text { Egu dui dubaduba o, } \\
& \text { O egu oroua dubaduba o. }
\end{aligned}
$$

Lifts it up and looks at it; addressing it he says :-

$\mathrm{O}$ natuguo dobi haragaharaga, heau haragaharaga;

1 Macgillivray, J., "Narrative of the Voyage of H.M.S. 'Rattlesnake," London, 1852, p. 274.

¿ Chalmers, Rev. J., "Pioneering in New Guinea," London, 1887, pp. 117, 118.

${ }^{3}$ Edae was the legendary introducer of sago from the west to the Motu and tribes on the eastern shores of the Papuan Gulf. 
When the bananas are bearing, and the time has come to cover them, he stands in the plantation and chants:-
Egumigumi mo e
Bamo be gumigumi e
Oi aubeghasi a gumigumi e
$\mathrm{O}$ bamo be aroberobe me aubeghasi
Aubeghasi aroberobe moe e-e-e-e.

When finished tying, he stands and turns towards them all and chants :-

E au mia e

Sinahu lau mia e

Daha rasenai e

Sinahu lsu mia e-e-e-e.

Used when planting yams :-

Asinavari daudau (four times).

Huevara daudau , ,

Bedovari daudau ,, ,

Naevari daudau , , ,

Eogovari daudau ,", ,

When the yams are just appearing above ground :-

Sinari kenikeni (twice).

Hueri kenikeni ,,

Ruela kenikeni ,

Naera kenikeni ,

Concerning these songs Mr. Chalmers' says "I made many efforts to discover the meaning of these songs, but the natives themselves have no knowledge whatever of their purport."

In the "Annual Report on British New Guinea" for 1890-91. Mr. R. Guise gives some specimens of Ballads and Songs in the dialects of tribes in the Central districts of New Guinea. I transcribe these in full. ${ }^{1}$

\section{LEKU-LEKU.}

(Ballad recording noteworthy events in the history of a tribe.)

These particular portions are in a language which is not spoken in this neighbourhood and are the oldest verses of the song known. It resembles the language spoken by the tribes inhabiting the south end of the Macgillivray Range.

I.

Kita vetali vetalimina Wapuli Wapuli Roga is talking of Roga kila vetali vetalimina. fighting, is talking of fighting.

1 1892, Queensland, "Annual Report on British New Guinea from 1st July, 1890, to 30th June, 1891." Appendix GG, "Native dialects," p. 108, "Vocabulary of Bula'a dialect." Preface by R. Guise, Ksq. 
II.

Alepa melo gemi melina bua The Alepa men were coming rigona pakini roli pitagoana. armed. We drove them away.

III.

Kara gota revaluai leva tu- Should we throw a spear, a puna.

man is hit.

LEKU-LEKU, from Kwaipo, in the Macgillivray Range.

Oi babine aririgo taona tena oaririgo aririgona. Leku leku, \&c.

Varaina gela malaga varaina variana roka keto vegata. Leku, \&c.

Oi babine tipi ono koro maina. Leku, \&c.

Nege pune maoma kora verariana. Leku, \&c.

Nega vanuga nuganana origo auna rage auna. Leku, \&c.

O you woman, softly walking, softly creeping.

O you man, you come from afar, and fall on the path.

O you woman, catch a quail with a hand net.

O you girls, who is strong to catch a pigeon.

Inside the village, let us march up, let us march down.

LEKU-LEKU, a later composition, written in the tongue used in Kamali.

Olulaga oi buikima maniga pala popolona opuru wai puru voina leku-leku ve leku.

Olulaga oi gimamu kora legenáanegi manega amo nana namo amo taliana.

Olulaga irunaga dubu vili wai poráage.

Oi tauna kone melo gili wana mo gitana.

Oru manu naro gege lagi nama.

O, Olulaga, your hair is thick and long as the leaves of a "popolo."

O, Olulaga, when you shake your kora (man-catcher) a heavy dew falls.

O, Olulaga, with the handsome face, you hanged the head on the dubu (sacrificial stage).

Come, look at the boy from the bush, playing on the shore with a white crane.

I am like a red parrot, I fly away and return.

Vanuganani gera olo vanuganai ora gena gipa manu noveni varáa varáana.

Gilalaka Tamolaka kila veagi veagimu ma Molegolo ropina pana kepoleana.

There is a village on the summit of a hill where men are taught wisdom by an eagle hawk.

Gilalaka and Iaomolaka, boasting who of us is strong enough to overturn the platform on Molegolo. 
Molegolo avalana lau minana minana poro kulou melau minu vagi ana.

Polo kulo kilamu lai nevaina oru aueku noi nepinu pinuana.

Tinara ularana gena gemo kakona pe gau rigo wagira Kalo vanuganai pelewa kamu lavilavina.

Melo tariku mo rakáauta mo gurana mo rakáanta ulanana mole konena mo tulu tepatepa na.
When the north - west wind blows lightly on Molegolo, your head-dress of feathers will be displaced.

I do not want a head-dress, I will bind twine around $\mathrm{my}$ ankles.

Our mother is at Kalo, where the sun sets, let us be like the gemo (a fish) and seek her out.

My brother, what are you carrying; and what are you doing in the water, splashing it about with your feet.

From the Papuan, as distinguished from the Melanesian districts of New Guinea we have few specimens. The Rev. J. Chalmers gives the following "Song before smoking" from Vaimuru, in the neighbourhood of Bald Head. It is said to have no meaning. ${ }^{1}$

$\begin{array}{ll}\text { Arau mai e! } & \text { Api amē ! } \\ \text { Io mari ē ! } & \text { Iau ē ! } \\ \text { Erere mai e! } & \text { Aaumako e! } \\ \text { Aueva e ! } & \text { Iau ē! } \\ \text { Io mari e e! } & \text { Kuku! Ueako ! }\end{array}$

The words and tune of a song from Muralug or Prince of Wales' Island in Torres Straits have been given by Professor Haddon in his account of the Ethnography of the Western tribe, ${ }^{2}$ and also in his description of the dances of Torres Straits. ${ }^{3}$ The words of this differ a good deal from the common speech, and are difficult to translate.

\section{Songs from the Solomon Islands.}

With the exception of the songs collected by Lieut. Somerville, which follow in the second part of this notice, I only know of the following song given by Mr. C. M. Woodford in the language of Aola, on the north-east coast of Guadalcanar Island. ${ }^{4}$ No translation is given.

Te mani, to mani,

To kai sambelagi mi,

Sambelagi tete mi,

Tete mbili-mbili loko mi,
Loko petepete mi,

Petepete uli mi,

Uli mani kande mi,

Kande ma kondo mi,

1 Chalmers, Rev. J., "Pioneering in New Guinea," London, 1887, p. 68.

2 Haddon, A. C., "The Ethnography of the Western Tribe of Torres Straits," in "Journ. Anthrop. Inst.," xix, 1890, pp. 378, 380.

" Haddon, A. C., "The Secular and Ceremonial Dances in Torres Straits," in "Internat. Archiv für Ethnographie," Bd. ri, 1893, p. 148.

4 Woodford, C. M., "A Naturalist among the Head Hunters," London, 1890, p. 39 . 
Saria bombotoni mi,

Eo mai-u-ai mi,

Eo eo kiki mi,
Ki kiki rongo mi,

Ro rongo kindia mi, Tindisotio.

The language is practically that of the island of Florida, and some of the words are intelligible, but I cannot make coherent sense of the entire song.

In the following portions of this paper are given some songs collected by Lieut. Boyle T. Somerville, R.N., during a surveying voyage of H.M.S. " Penguin" on the coast of New Georgia. The language of this island is best known by the vocabulary (in four dialects) by Lieut. Somerville, which has been printed for the Hydrographical Department of the Admiralty. ${ }^{5}$ An account of this publication appeared in the "Journal of the Anthropological Institute for November, 1896."

The dialects of the songs and of the story which follows them are those of Rubiana in the south-west lagoon and of Marovo, the general dialect of the coast natives. The language presents many divergences from the usual type of Solomon Island tongues.

In what follows the songs and story are given as Lieut. Somerville wrote them and with his own notes and translations.

\section{Part II.-Sonfs from New Georgia, by Lieut. B. T. SoMerville, R.N.}
1. "Sitima Belapura." (Balfour's Steamer : i.e., H.M.S. "Penguin.")

Marovo or Eastern Dialect.

The song apparently describes the arrival of H.M.S. "Penguin" in the Marovo district of New Georgia. The part concerning Kelly and Griffith (the former a trader of Rubiana, the latter of Ngarasi, on tho Northern Coast) is obscure. The two boys who gave me the words, made signs that it referred to the (apparently) handcuffing of some one. I could connect it with no incident that came to our knowledge either on board the "Penguin" or in camp.

The last fives lines seem separate, and went to a different chant to the remainder.

Names in italics are those of places in the locality known to us.

Englandi Americana serosere Mbuka Nuki kiona pa India, pa

Nunggini. coasts (?)

New Guinea.

Pa tu Laiti, pa tu Mata, pa tu Lila, pa tu Kevu, pa tu Mata. Past (?)

5 "A Vocabulary of Various Dialects used in New Geopgia," compiled by Lieutenants B.T. Somerville and S. C. Weigall, R.N., H.M.S. "Penguin," 18934-5. Hydrographic Department, Admiralty, 1896. 
Hore pa sera Marovo, boro Chiri, boro Kara, boro 'Tolu, boru Mane, Down by coast (?)

boro Chiri, boro Toa, boro Kiva.

Hore mai pa kolo Checheu, pa kolo Nele, pa kolo Chalu, pa kolo Down go by open sea

Dolunggu, kolo Onuku.

Hore mai pa boro Kua, hono hore mai pa kolo Kicha, pa Down go by down come by open sea (two offMbulo; lying islands).

Hore mai pa Chipura, pa Enekonggu, hore mai pa Munjiana, pa Down go by down go Minjalai.

Katekatini pa Orooroki, Mbote, pa Bili Sangora, Bili Tolelo, Bili lupa, Bili Konggu: (Bili entrance to lagoon)

Kare Chombuani, kare Cholani: pa Karu-njiu, pa Karu-njuke, Not not (an island)

Chavichaviaui;

Mai pa Chochopo, pa Ngoru-ngorunu mati.
(a point)
reef.

Makasina hore la pa Sangara Lumalitie;

By and bye down go by (the Lumalike entrance) (facing Repi district), Mai pa mati Mbaku, mati Vehi, mati Vio, mati Onasanga, mati Come by (a reef in Lumaliki entrance) reef reef reef

Ndola, mati Ringgo. reef.

Hore mai pa Utuha: hore mai Lumbe Chalu, maniwa.

Down come by man of war.

Chake nia kwaka sitima ta Keripi, tingonea atisegoro pa steam-boat Grifjith (a trader)

Sydney konggu, pa Sydney Lupa, tonua kwina. queen.

Kwini ndoku pa pepelete atu kwaka pa sitima nahinini, kwaka Queen sit boat steamer. tenga Kiripi. Griffith.

Hore mai kwaka sitima Somerville, mai pa sera Okocho urungia steam-boat

Bera-bera.

Matui ngululu Kelli pia herani “Penguin," ka pa pa "Penguin." Kelly (a trader) 
Boro wa Kiripi tinoni limangu ka leli matau ni ene ni lapa ni koka Griffith

pini.

Talokete pia herani ngu pa Karu Tengguna, omi pa Karu pa Afraid here carry $I$ to see

Ndovela.

Pia herani ngu pa Karu Vindalu, pa Karu Nepichi, pa Karu Here carry I to (Many lagoon islets are considered double and

Kaminde, pa Karu Cheruma, Karu Kachona.

called Karu, two, in consequence).

Omi pa Karu Namburu, Karu Ngenggulu, ngu, talokete eraka. See afraid $I$.

Tapa meka wari wuke kisa machu pa maniwa.

One shark son man-of-war.

Nongge nongge kale matonde. side making (i.e. right hand side).

Panja punja kale hendende. side left.

Tapa meka wari ndumi pira he viri. one.

Tapa meka wari wuke tinoni pira. one man that.

Kisa machu maniwa.

Shark son man-of-war.

2. Kolomoru (The Night Wind).

Kolomoruna

Kawo Konji

Night wind the (name of a small stream at Repi)

Kawo Tsalu keli mai.

(Another small stream) up come

Kolomoruna longgi

Night wind

Chalu.

(probably Tsalu again).

Kawo pa Konji : temara pa Wamba

Kawa pa Tsalu, $\mathrm{m}-\mathrm{m}-\mathrm{m}-$.

3. The following song is sung to the same air :-

Monjenangara mbolembolena

Mbulimbolena telemba be la Kiripi.

Waka ta Repi, lulu pake masa.

$$
\text { Griffith (a trader). }
$$

Ship of Repi

Surangi Rakupisu, hero tsura pa kolo. (name of a man) open sea.

Honahapu pa Tsokura, pa Koveli, pa Khambu. 
4. This song is also sung to the same air :-

Tua longoa pa Patasiu

Oma me ngoa pa Karu Maneki

(Name of an island)

Mbemarono $\mathrm{m}-\mathrm{m}-\mathrm{m}-\mathrm{m}$.

Kurukuru pa Ndakolai

Pigeon

Angga hangga pa Reuvolo

Mbemarono $m-m-m-m$.

Kurukuru pa Mbekala

Pigeon

Ulo tamana, ulo tinana, ulo ndasine.

Weeps his father, weeps his mother, weeps his brother.

Chimbetusa ki narona $\mathrm{m}-\mathrm{m}-\mathrm{m}$.

Tira vare ngu karo kale

Tendo vendove $\mathrm{m}-\mathrm{m}-\mathrm{m}-\mathrm{m}$.

All these songs were given to me by one lad and they are sung to the same air. If the words fail before the end of the air is reached, the singer hums the remainder with closed lips.

The last song may be partly in the Mbariki, "bush" dialect, though it was given to me by a "salt water" lad. Mbemarono, in any case is Mbariki dialect for "name" or "your name."

5. Song accompanying war dance of Gatukai Natives. (Eastern Dialect.)

Pekapeka turu
Dance
Pekapeka turu
Dance
Polotu uasana
Egoria tsatsaveli
head
Turusangi.

6. The following was chanted by the Marovo district (also Mungeri) lads in derisive imitation of the mode of speech of the Gatukai men.

Ndeki ndeki pa Chaino-o-o:

Song-dance of

Lulu wa i ngua ngina lenggu hori kisa-a-a. wait (?) $I$ soon kill belov shart. 
7. A Rubiana song given to me by a small boy from Ngarasi.

\section{Kokohai.}

Koko hao ti-o-ke

Tani telso ti-o-ke

Koko hao ti-o-ke

Ngula teko ti-o-ke

Koko hao ti-o-ke

Tuma teko ti-o-ke

Piti koli ti-o-ke

$\mathrm{Pa}$ sa Saikile ti-o-ke

He Lilio ti-o-ke

Sa Sambeti ti-o-ke

Atu ngua ti-o-ke

$\mathrm{Va}$ tu khose ti-o-ke

Muki wose ti-o-ke

Asa puta ti-o-ke

Sasa puta ti-o-ke

Sighi tio ti-o-ke

Wuliwuli tio ti-o-ke

Dingudingu leagu ti-o-ke

Ngumo pitu ti.o-ke

Hele pitu ti-o-ke

Ngasa pitu ti-o-ke

Embe pitu ti-o-ke.
8. Song supposed to represent the sound of a Jew's harp. (Eastern dialect.)

Koioro.

Koi-oro paipa,

Koi-oro pepa,

Koi-oro pipa,

Koi-oro paipa.

9. Norowai.

Tótoro tiowai

Tótoro towao

Kíworo kíworo

Nórowai nórowai.

I was informed by the small boy who gave it to me, that this was a "hope" or sacred song. I repeated it to one or two men, but they did not know or understand it.

10. Two other songs given me by the same boy: (Probably Eastern dialect.)

Tombi.

Tembo témbolo

Tombi témbolo

Tamba témbo o.

Timba témbolo.
Inasi.

Kesa kesa

Kesa ruha

Kesa savoro

Oroketi

Tívula wawao

Revosia

'Túmaneki tumanegi.

\section{Part IIl. A Story in the Dialects of New Georgia.}

A short story, not an original native one, but composed for the occasion. I in English, II in Island-English, III in Marovo. IV in Rubiana.

The story was first done into Rubiana by a native understanding English fairly well, and afterwards from Rubiana into Marovo, by a native understanding both tongues, so that whatever mistakes are in the Rubiana, the same are in the Marovo as regards the original English. 


\section{I.-English version.}

Once upon a time, a man called Tasa went out to the Tomba Islands (the barrier islands that surround the North Coasts of New Georgia) to spear fish.

After a little while he caught a makasi, and had just placed it in his canoe, when another makasi came, and putting his head out of the water thus addressed him:- "Why have you killed my wife? By and bye my children will all die if they do not get their food from her."

Tasa replied, "Yes, but don't you see that my children will die too if they do not get fish to eat." The makasi returned, "Very well then, I shall go and tell my friend the shark, and he will catch hold of you, and kill and eat you." And he disappeared into the sea.

However, Tasa went on spearing fish, and when evening came he hoisted his sail to start back home to Mungeri. Hardly had he done so before a great wind rose, with rain, thunder, and lightning. His canoe quickly capsized and was broken by the waves, and Tasa began to swim for his life. However, the makasi had been as good as his word, and he came, bringing with him a shark and a crocodile. The shark seized Tasa by the head, the crocodile by the legs, and they tore him in two before his screams could call the attention of his friends.

Then the makasi laughed, and, going home, soon got another wife, who looked after the children so that none of them starved.

\section{II.-The same story in Island-English.}

Long time before, one fellow man, name belong him he Tasa, him he go along Tomba, along canoe catch him fish along spear. By and bye one fellow makasi he come, him he catch him, him he put him along canoe. Close up another fellow makasi he come, he put him head belong him out of salt-water, he sing out, "What name you shoot him woman-makasi belong me? by and bye altogether picaninny belong me he die suppose he no catch him kaikai belong him."

Tasa, him he talk, "What name you talk him, suppose picaninny belong me he no kaikai makasi, he all o'same picaninny belong you, altogether him finish, he die." Man-makasi he sing out: "All right, you look out, me go talk him shark, by and bye he kaikai along you." Him he go away along saltwater.

Tasa he go, he shoot him plenty fish, sun he go down, he put him up sail, he go quick along Mungeri. Big fellow wind he come, rain he come, plenty thunder and lightning he come, canoe he capsize, canoe he broke, Tasa he swim, he swim along. Shark he come, crocodile he come, Man-makasi he come, shark he catch him Tasa along head, crocodile he take him along leg, he pull, be pull plenty hard. Tusa he sing out, no man he come, by and bye he broke, he finish. 
Makasi he laugh : him be go place belong him, he catch him another fellow woman : picaninny belong him he no die.

$$
\text { III.-The story in Mârovo or Eustern dialect. }
$$

Mekarani lavata, meka kilana, meka tinoni Tasa la pa Before big one name one man Tasa go to

Tomba, bambao ighana.

Tomba spearing fish.

Pana ngina ighana makasi heru mai hinambu, hinambu

On the soon fish makasi carry come

makasi ngina raihi. Walusa pa mola na makasi. Her'u makasi soon Placed (?) in canoe the makasi Carry mai makasi panangina mekarani. Vurama pa kolo makasi come makasi soon before from ocean makasi

"Hoi honama manemaneki tanguraka sa mbohoronia tamhoi? You woman mine why your

lenggu mbeto kombura tanguraka, kani vai niningo lelenggu die altogether children mine not fish die komburu." children.

Tasi seki tinana. "Sa njiama ni hamu kani ngongo soku Tasi killed mother. Why talk it you not it eat enough

komburu tanguraka, kande ngongo komburu ndio la va." children mine it is not to eat childven.

Njiama ne ta sa makasi, "Omia chake nia makasi manda va lusa : Talk makasi Look $I$ it makasi

omia sa kiso moko ta usu ma nia ngu lenggu ngua." look I shark of it come I die I."

Chongga la pa inderi ia.

Dive go in sea him.

Chokuna ighana va la i pa ngongo katingga. Njoro wo ini wa Many fish go it to eat some. Set sun toia tepe, pule mai pa Mungeri. Ngetena cherani live it sail return come to Mungeri. Big hurricane (?) are panagina ipu, na mungata, na rani, na paratata, wind soon night the rain the day(?) the thunder umbata, na ragi, are. Ngina opo mola, opo takuri, surf the wave wind. Soon capsize (?) canoe broken opo pomi tinoni, kiso basioto, na vua, na makasi. man shark crocodile.

Herua kiso chaveh hataomi tera, la hua usu kuri mahile; la ia Took shark head leg go it wai lima mahile hata omi. Tasa kukeli, kukeli, kani five legs. T'asa sung out sung out not (they) 
mai. Makasina takuri mbeto.

come. Soon torn finish.

Chomu makasi la pa kolo, manda wa lusa tinoni.

Makasi go to ocean

man.

Meka hokiti manemaneki, kani lenggua komburu tania.

One buy (?) woman not die children his.

Note.-There are several places where the English meaning has evidently not been apparent: and, indeed, the whole story seemed a strange sequel of sentences to the interpreters without a familiar idea, or anything which made sense, while it was being translated bit by bit. Once or twice they appear to have translated the little bits of side explanation which were made to them, not as part of the story but to elucidate the meaning of some particular clause.

\section{IV.-The Story in Rubiana dialect.}

Pukerani lavata, keke posana, keke tie Tasa ila pa Tomba hi Before big one name one man Tasa go to Tomba hena hopere na ighana. catch spear the fish.

Ngina igana makasi hena mai siramu, wagi makasi siramu hena. Soon fish makasi.

Surangi pa mola ra makasi. Kohite imaisa makasi keke wo Put in canoe makasi.

ti kaina. Vurana mbatuna ra makasi, vura pa kolo: Put up his head makasi put up from ocean

"Agoi sigona sa mbareka lengge tangurao, na sasi bugoro nia si agoi, kote mate mbeto puku komburu tangurao, lopu hena soon die altogether children mine not get

khinane, kekanggu mati.

$$
\text { food dead. }
$$

Tasa se jeama agoi. "Sa sejeama ni siramu wenagua ke lopu Tasa talk $I$. not

khanikhani so komburu tamu agoi, ke kangu mate ke lopu food children thine not die not

khanikbane." Njiama me tu sa Makasi. Dogoriatu hakefood. Tallo Makasi.

niatu mamu kukilinia manda la ia. Dorea sa kiso meke Shark

tararatanea manda vovete nia tu. Hako tararata arao ke hako mati angua. Arao hongga la pa kolo.

$$
I \text { dive (?) go into ocean. }
$$

Taloa si khita sigona soku igana manda khanikhani.

$$
\text { Plenty fish fool }
$$


Londu sa rimata we ko matana sa tepi, awugo ra sa arimiata pule sun

san return

mai pa tani Mungeri. Nomana rani mbongi pe mai sa come to that Mungeri. Long day night come

iguchu, hote mai sa ruku, kote meke paka, fire(lightning?) come rain soon gun (thunder?) samangaru kalijerua meke kapi. Kote meke opo sa mola, bad.

Soon canoe

meke moku, meke tunoro, meke rani ramda kiso, basietto, break shark crocodile

mai sa Makasi. Mai wagia sa kiso sa mbatu palekia taloa come Makasi. Come the shark the head take

lopu ta ndaoro. La sa mbasietto kharettia nene kele tamoku. not of.

Go the crocodile

Laso meka wagi sari na limana nene. Tasa kukeli, lopu mai foot (?) Tasa sing out not come

sa tie. Kohiti moku mbeto.

a man break finish.

Heghari sa makasi la pa kolo mandu wa lusa ia.

the Makasi go to ocean.

Keke wotiki mbareka lengge. Lopu mati sa komburu tamu agoi.

One buy (?) woman. Not die the children thine.

\title{
Native Dyes and Methods of Dyeing in Korea.
}

\author{
By E. B. Landis, M.D.
}

ALthodgh it is scarcely a dozen years since Korea was first opened to foreign commerce, yet in that short time native dye-stuffs have been almost supplanted by the cheaper and better aniline dyes. Few of the native dyes are now in use, and those only in the more remote portions of the country. Of some it is almost impossible to obtain specimens, and of others the difficulty is less only because they are used in medicine or for other purposes than dyeing. This difficulty, of course, only refers to the prepared dyes, the plants and trees from which they are obtained being indigenous, will always remain.

\section{Red Dyes.}

1. Cha Cho 紫 草. Obtained from the roots of the Lithospermum officinale L. var erythrorhizon.

2. Hong Hwa 紅花. This is the dried blossoms of the Oarthamus Tinctorius $L$. It is largely cultivated in gardens, both for its flowers and for its use as a dye. It dyes a bright scarlet. These dried blossoms are also used largely in medicine, being a favourite remedy for aches and pains.

VOL. XXVI. 